\title{
廃棄物処理の動向
}

\section{Present and Future of Waste Disposal}

\author{
寺嶋 均 \\ Hitoshi TERASHIMA
}

Key Words : Waste, Disposal, Law, Technolgy, Trend

\section{1. 廃棄物処理の現状}

廃棄物は,「廃棄物の処理及び清掃に関する法律 (以下，「廃棄物処理法」という)」にもとづき，一般 廃育物と産業廃棄物に区分され, 限定列挙された産業 廃棄物は排出事業者か，その他の一般廃棄物は市町村 が処理責任を負うことになっている。

\section{1 一般廃棄物}

厚生省の発表によれば，平成 8 年度における国内の 一般廃棄物排出量は 5,115 万トンで, 国民一人一日当 たりの一般廃棄物排出量はこのところ横ばい傾向にあ り，1,114グラムとなっている。

これらの一般廃棄物は, 焼却や資源化等の中間処理 によって $89.7 \%$ が減量化され, 残り $10.3 \%$ が直接 埋立処理されている。リサイクルの状況は年々上昇し てはいるものの, 約 $10 \%$ にとどまっている。

一方, 平成 8 年度末における最終処分場の残余容量 をみると 141,000 万 $\mathrm{m}^{3}$ で, 残余年数は 8.8 年となっ ている。

\section{2 産業廃棄物}

同じく厚生省の発表によれば，平成 8 年度における 国内の産業廃棄物排出量は，40,500 万トンと一般廃 棄物の約 8 倍になっている。

リサイクルの状況は $42 \%$ と一般廃棄物より高い

2000 年 3 月 17 日受付

（社）全国都市清掃会議

（テ113-0033 東京都文京区本郷3-3-11，IPB お茶の水ビル7階） TEL 03-5804-6281

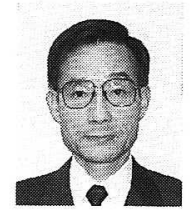

<著者紹介>

昭和 35 年早稲田大学理工学部機械工学科を卒 業。元東京都清掃局施設部長。現在は社団法人 全国都市清掃会議技術部長。

専門は廃棄物処理技術, 環境保全技術、廃茶物 処理計画論
が, 最終処分場の残余年数が 3.1 年しか残されていな いことが大きな問題である。

新規の焼却施設や最終処分場の許可件数について は, 平成 8 年度以降, 廃棄物処理施設のダイオキシン 問題や産廃の不適正処理の報道等により, 住民の激し い反対運動が多発したため, 極端に減少している。こ のため, 近い将来において産業破棄物の適正な処理体 制を確保できるか，危惧されているところである。

\section{2. 廃棄物処理行政の動向}

\section{1 廃棄物処理・リサイクル関連法令の変遷}

廃棄物処理とリサイクルに係る関連法令の変遷につ いては，図 1 に示すとおりである。

近年, 資源循環型社会の構築をめざすリサイクルの 推進・廃充物処理施設に起因するダイオキシン問題の 解決・頻発する産業廃虽物の不適正処理対策等に対す る強い社会的要請に答えるため, 目まぐるしいほどに 法令が新規制定・改正されている。

平成 3 年以降に新規制定された廃棄物処理・リサイ クル関連法令は, 以下の 5 法令もある。

(1) 再生資源利用促進法

(2) 産業廃棄物の処理に係る特定施設の整備に関す る法律

(3) 容器包装リサイクル法

(4) 家電リサイクル法

(5) ダイオキシン類対策特別措置法

さらに，2000年を「循環型社会元年」と位置つけ て, 通常国会に以下の 6 本の法律が提案されている。

(1) 循環型社会基本法案

(2) 廃棄物処理法改正案

(3) 再生資源利用促進法改正案

(4) 建設工事に係る特定資材の再資源化等に関する 法律案 


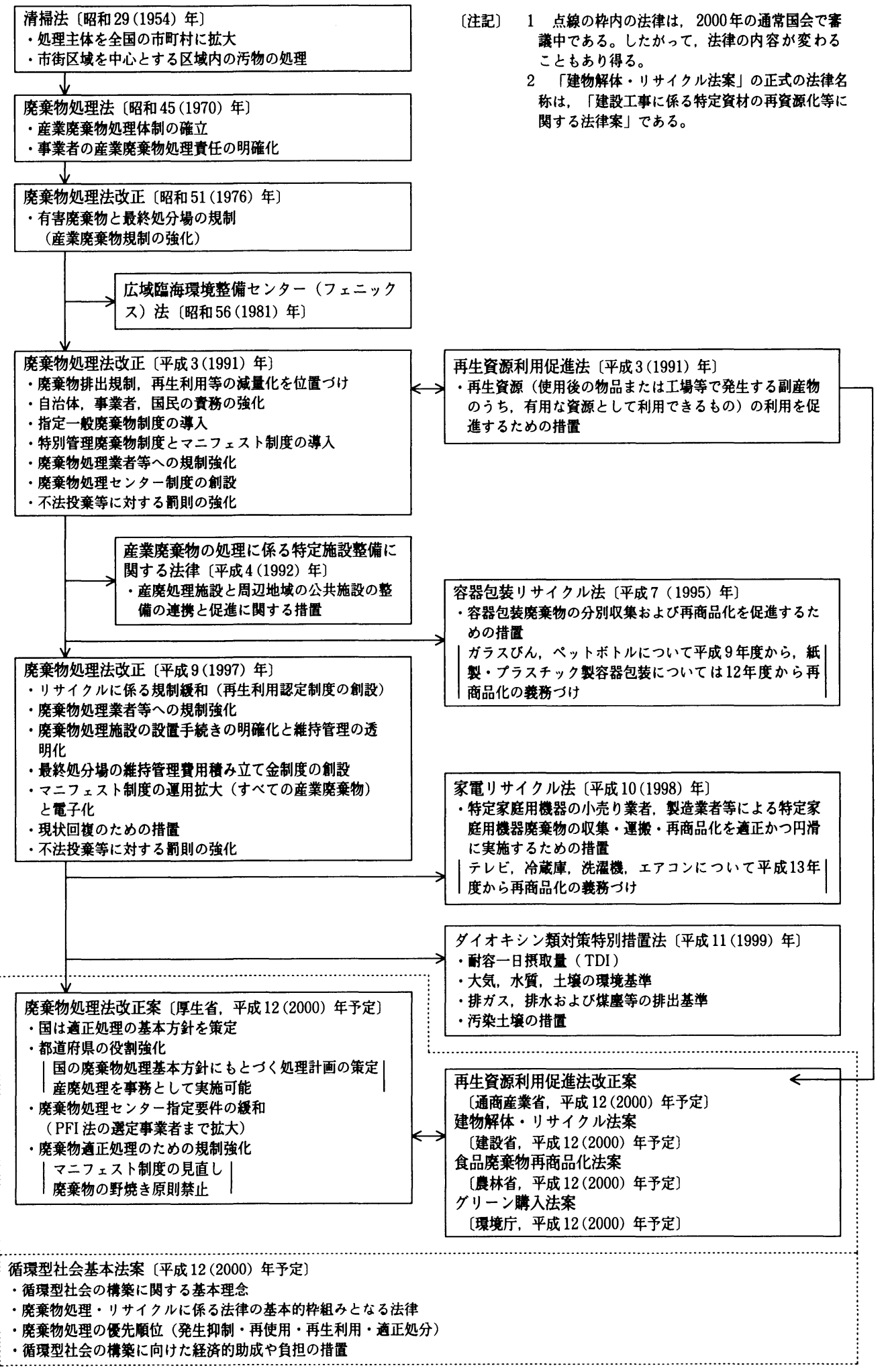

図1廃棄物処理・リサイクル法制の変遷 
(5) 食品廃棄物再商品化法案

(6) グリーン購入法案

2.2 廃棄物処理・リサイクルの制度構築

2. 2.1 産業廃棄物の処理施設不足と不適正処理 問題

市町村が処理責任を有する一般廃棄物の処理施設に ついては, 近年, 能力的・性能的にもかなり充実して きている。しかし, 排出事業者が処理責任を有する産 業廃棄物処理施設については, 能力的・性能的にも十 分でない状況が見受けられる。特に産業廃棄物埋立処 分場の窮迫は, 不法投棄や有害廃棄物の海外輸出等, 大きな社会問題を惹起しており, 早急な対応が求めら れている。

\section{2.2 地球環境問題の激化と忍び寄る資源枯渇} 問題

(1) 地球温暖化問題への真剣な対応の必要性

1997 年末の COP3 で京都議定書が採択され, 日本 は, 2008年から 2012 年までの 5 年間平均の温室効果 ガス排出量を，1990年対比で $6 \%$ 削減する義務を負 うことになった。日本では, 特段の削減対策をとらな かった場合, 2012 年時点における炭素換算 $\mathrm{CO}_{2}$ 排出 量が, 1990 年対比で約 $20 \%$ 増加すると予測されて いる。

したがって，約 $26 \%$ もの $\mathrm{CO}_{2}$ を削減せざるを得な いが、これは容易なことではない。このため，今後の 廃棄物処理のあり方についても, $\mathrm{CO}_{2}$ 削減義務が大き な制約条件として浮上してくるものと考えられる。

(2) 資源枯渴の危惧

科学技術庁資源調査会の「21 世紀の日本の資源に 関する調査報告」によれば，全世界の資源の確認埋蔵 量を生産量で除した耐用年数は，表 1 に示すとおりに なっており，余程の技術進歩がないかぎり 21 世紀の 後半には, 豊かな現代文明を維持していくだけの資源 を確保できない事態が起こるものと予測される。特に エネルギー資源については，絶対的な枯渇以外に，偏 在性・対外依存性・政治的不安定性等の多くの問題を 抱えている。

近い将来, 資源枯渴が憂慮される時代にあって, 大 量生産・大量消費・大量廃棄を基調とする現在の市場 経済を，いつまで続けていけるのかということが問わ れているようである。

\section{2.3 財政の穹迫化}

国と地方自治体の長期債務残高は, 平成 12 年末 で約 650 兆円であり, 約 500 兆円の国内総生産高 (GDP) の 1.3 倍と，日本の財政は先進国で最悪の状態
表 1 世界の資源耐用年数

\begin{tabular}{|c|c|c|c|}
\hline \multicolumn{2}{|c|}{ 区 分 } & 可採年数 & 備 \\
\hline \multirow{4}{*}{$\begin{array}{l}\text { エ } \\
\text { 衤 } \\
\text { ギ } \\
\text { I } \\
\text { 資 }\end{array}$} & 石 油 & 43 年 & \multirow{4}{*}{$\begin{array}{l}\text { 出典 } \\
\text { 「総合エネルギー統計 } \\
\text { 平成 } 9 \text { 年度版」 }\end{array}$} \\
\hline & 天然ガス & 62 & \\
\hline & 石 炭 & 231 & \\
\hline & ウ ラン & 73 & \\
\hline \multirow[t]{2}{*}{ 金 } & 鉄 & 65 & \multirow{4}{*}{$\begin{array}{l}\text { 出典 } \\
\lceil\text { US Bureau of } \\
\text { Mines 1995」等 }\end{array}$} \\
\hline & 銅 & 33 & \\
\hline 資 & 鉛 & 22 & \\
\hline 源 & 垔 鉛 & 20 & \\
\hline
\end{tabular}

にある。これは，影気対策のため公債の増発を重ねて きた結果である。地方自治体にとっては，本格的な少 子高齢化社会が到来した場合, 介護保険の導入による 福祉予算等の增加が求められるので, 一般廃棄物処理 事業への財源配分が，これまでより削減される恐れが ある。

このような財政破綻（破産）が危惧される現状にお いて, 近年, 民間の資金や経営ノウハウを活用して社 会資本を整備するPFI の導入が, PFI 推進法の制定 にともない，注目を浴びているところである。

\section{2.4 資源循環基本法の制定化に向けて}

20 世紀の経済成長を導いた大量生産・大量消費・ 大量廃棄システムは，環境破壊と資源浪費をもたら し，循環型社会への転換が急務となっている。このた め, 個人や企業の複雑な利害を総合調整できる制度と して, 現在「循環型社会基本法」が 2000 年の通常国 会に提案されている。

現在，発表されている法律案の骨子によれば，この 法律は, 廃棄物処理・リサイクル関係の法律の基本的 枠組み法と位置づけられるものである。内容的には, ヨーロッパの廃棄物戦略である以下の各戦略が, どこ まで法律案に取り込めるかが議論されているところの ようである。

(1) 予防原則 (廃棄物処理の優先順位)

i 発生抑制

ii 再使用

iii 物質回収

iv エネルギー回収

$\mathrm{V}$ 適正処理

(2) 污染者負担の原則（事業者責任）

(3) 協働化原則（拡大生産者責任）

とにかく，これまでのように，廃棄物を焼却して埋 


\begin{tabular}{|c|c|c|c|c|}
\hline 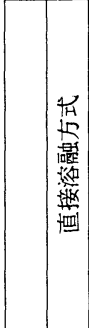 & 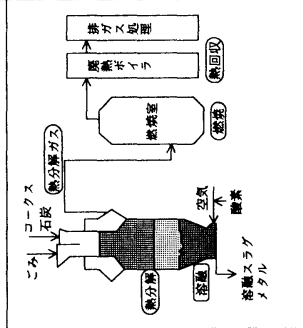 & 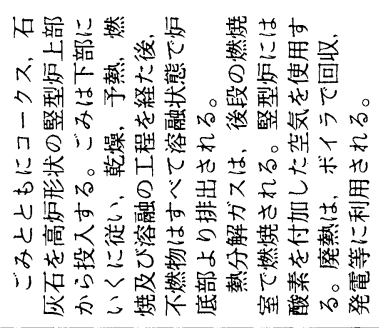 & 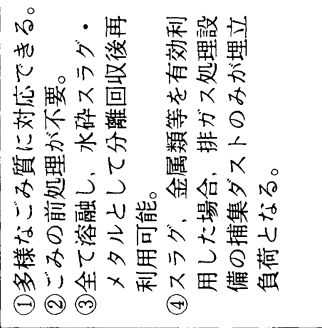 & 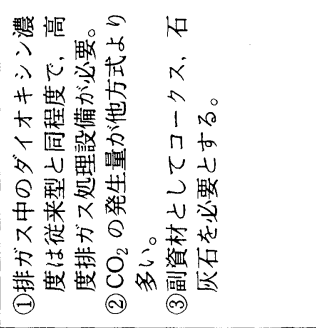 \\
\hline 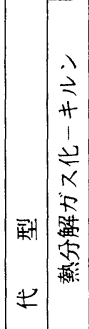 & 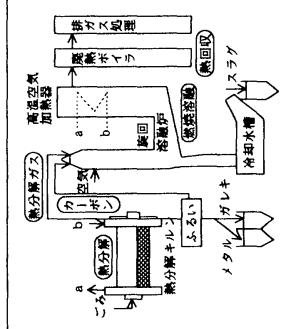 & 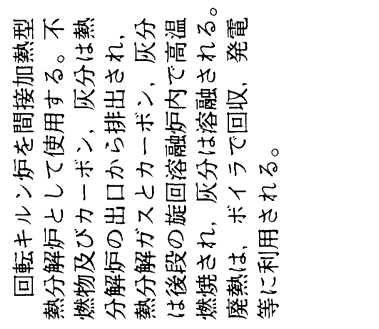 & 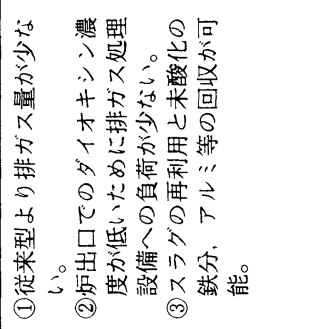 & 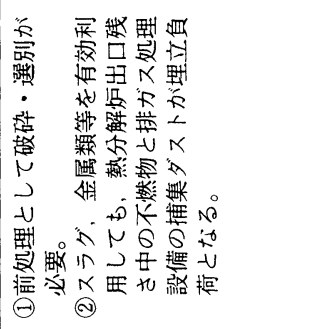 \\
\hline 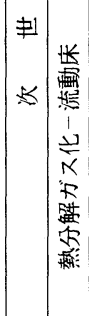 & 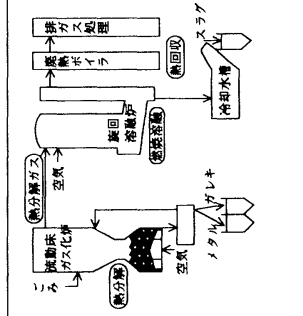 & 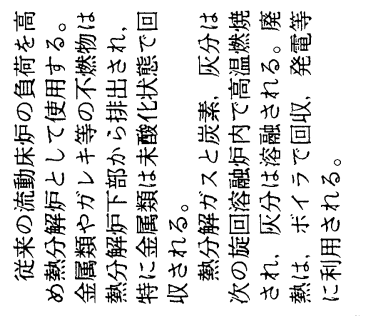 & 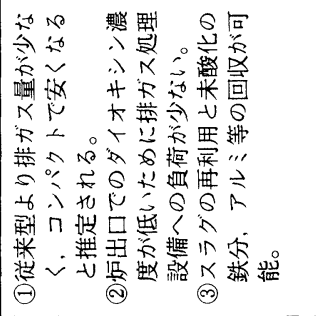 & 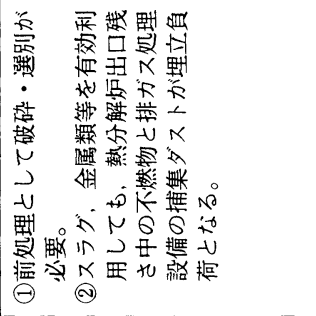 \\
\hline 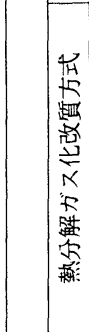 & 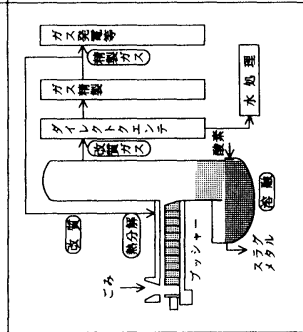 & 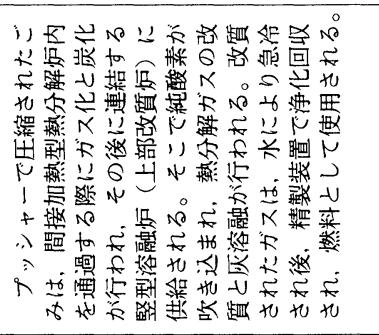 & 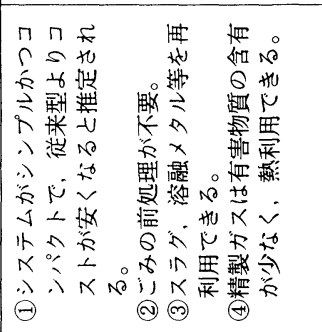 & 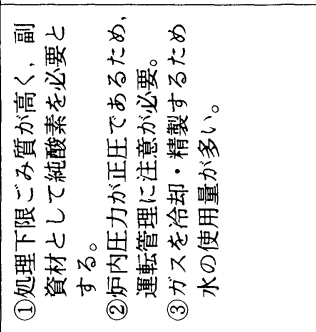 \\
\hline 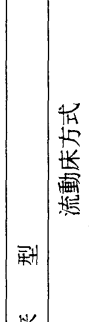 & 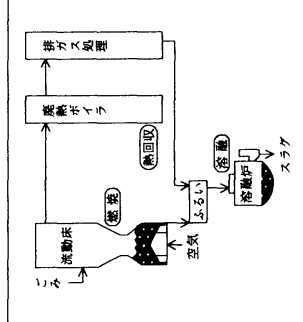 & 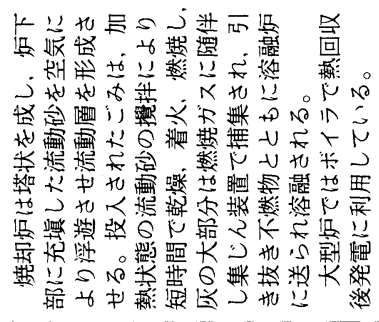 & 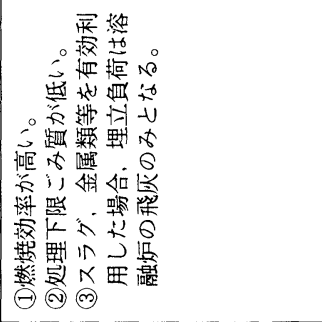 & 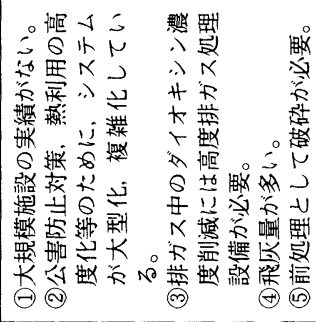 \\
\hline 奖 & 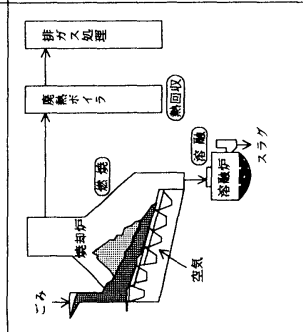 & 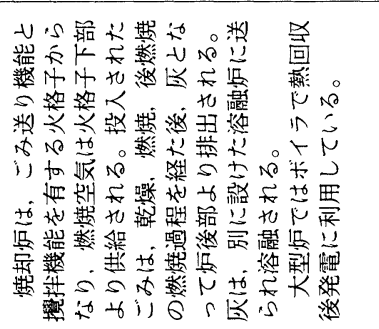 & 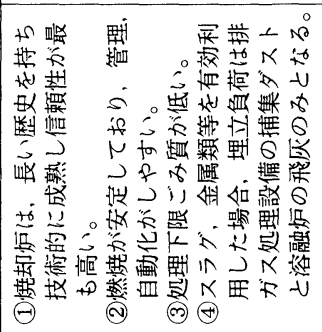 & 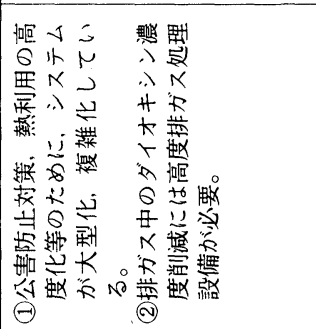 \\
\hline 四 & & 缕 & 㫮 & 盎 \\
\hline 鄙 & & 垡 & 此 & 味 \\
\hline
\end{tabular}

Vol. 37 No. 6 (2000)

(13) 
め立てる社会から, 循環型社会の構築に向けて急いで 舵を切るため, 海図の整備が求められている。

\section{3. 廃棄物処理技術の動向}

\section{1 焼却技術の課題}

現在，日本における都市ごみ（一般廃棄物）の中間 処理技術は，ごみを直接焼却する技術が主流となって いる。

しかしながら，長い歴史を経て成熟し高い信頼性と 実用性を誇ってきた焼却技術も，時代の変化にともな い市町村（ユーザー）の立場から，以下のような 4 課 題の解決を迫られるようになっている。

（1）ダイオキシン削减への厳しい社会的要請

ごみを焼却処理すると副産物としてダイオキシン を放出することから，非常に問題であるとの社会的 な非難から，ダイオキシン問題を発生させない中間 処理技術の早急な開発が求められている。

（2）埋立空間の大幅な節減化または不要化

国土が狭く人口も稠密で都市化の進展も著しい日 本において，廃棄物の埋立空間（最終処分場）は, 有限で枯渴性の希少資源である。近い将来における 埋立空間の窮迫に対して, 長期的に安定した都市ご みの処理体制を維持していくためには, 埋立空間の 大幅な節減化または不要化ができる中間処理技術が 求められている。

（3）再資源化性能の向上と地球環境問題への対応

ごみ焼却施設における物質回収は，焼却残さ中の 灰まみれの鉄分を選別し，逆有償で引き取ってもら うような現状にある。エネルギー回収の発電効率 も, 電力会社と比較して半分以下の状況にある。こ のため, 再資源化性能の向上が強く求められてい る。

また，再資源化性能の向上に伴うごみ処理施設外 への回収物の逆流により, 処女資源の採取を減少さ せ，地球環境へのインパクトの減少を図ることが望 まれている。

（4）シンプル化とコンパクト化による経済性

現在のごみ焼却施設は，公害規制強化への対応や 発電等の余熱利用の高度化をはかるため, 非常に複 雑・大規模な技術システム（プラント）となってお り，建設費・維持管理費も高騰している。

このため, よりシステムのシンプル化とコンパク 卜化が可能で，ごみ処理コストを低減できるごみ処 理技術の実現が求められている。

\section{2 新技術（次世代型技術）の開発状況}

3. 1 のごみ焼却技術の 4 課題を解決するため，近 年, ガス化溶融方式やガス化改質溶融方式と呼ばれる 新しいごみ中間処理技術の開発が進展している。その ような新しいごみ中間処理技術の概要を, 表 2 に示 す。これまで主流であった焼却技術から新技術へ，い つの時点で転換を図るのか, 信頼性・実用性（安定稼 働性等）の早急な検証・確認が待たれているところで ある。

\section{4. おわりに}

廃棄物をリサイクルするには, 膨大な人手・経費・ 資源エネルギー等を必要とする。このため, 極力, 廃 育物の資源循環を図るにしても，LCA や経済性等の 面から多面的な検討評価が必要と考える。

現在,「資源循環型社会の構築」が, 日本がめざす べき目標として声高に叫ばれている。しかしながら，

「資源循環型社会の構筑」とは，廃棄物のリサイクル が積極的に推進されるよう，社会構造の一部を変えよ うとするものに過ぎない。日本の社会全体が長期的に めざすべき大きな国家目標は，別にあるのではないか と考える。

このような「資源循環型社会の構築」という手段レ ベルの発想を国家目標に設定していることが, 今日の 廃棄物処理を含む環境・資源問題の効果的な解決に, つながらない一原因になっていると考える。

現在,「市場経済 (自由競争)」がグローバルスタン ダードの一つとされている。一方，人間の活動能力が 地球の持つ自然净化・生産能力を超えて, 地球環境問 題の激化や資源の枯渇が憂慮される今日, 今後の社会 がめざすべき目標として，「持続可能な社会」という キーワードも提唱されている。

「持続可能な社会」とは，あいまいさが残る表現で あり，より具体的な表現としては，人間と自然が有限 の世界の中で，お互いに尊重と節度を保って末永く生 きていくという「環境共生型社会 (表 3 参照)」とすへ きであり, 資源循環型社会論は，このような未来社会 を実現するための一手段として論議されるべきである と考える。

廃棄物問題の根幹には人々の価値観（生きかた）が 深く係わっている。「物があることが豊か」という価 值観で私達は, 大量生産・大量消費・大量廃棄という 社会を作り上げてきた。

しかしながら, 環境共生型社会の構筑にとって最も 重要なことは, 人間がこの有限な地球上で永続的に生 
表 3 社会の発展段階と廃棄物処理の変遷

\begin{tabular}{|c|c|c|c|c|c|}
\hline \multicolumn{3}{|c|}{ 社会の発展段階（都市施設に要求される機能の階層） } & \multirow{2}{*}{$\begin{array}{l}\text { 年代 } \\
\text { (西暦) }\end{array}$} & \multicolumn{2}{|c|}{ 廃棄物処理行政の変遷 } \\
\hline \multicolumn{2}{|c|}{ 社会規範（都市施設例） } & 機 & & 廃棄物処理の目標 & 理由と施策例 \\
\hline 安全性 & $\begin{array}{l}\text { (1) 防犯施設（警察等） } \\
\text { (2) 防災施設（堤防等） } \\
\text { (3) 国防施設 }\end{array}$ & $\begin{array}{l}\text { 生存環境の確保 } \\
\left(\begin{array}{l}\text { 人間生存の基盤 } \\
\text { を確保 }\end{array}\right)\end{array}$ & $\begin{array}{l}\text { ～明治初 } \\
\text { 期以前 }\end{array}$ & $\begin{array}{l}\text { 自家処理 } \\
\text { (個人もしくは部 } \\
\text { 落単位) }\end{array}$ & $\begin{array}{l}\text { •大都市江戸の廃棄物処理は, 徹底的な } \\
\text { リサイクルをベースにして組織的に行 } \\
\text { われ, 当時の西欧における大都市より } \\
\text { クリーンな都市であったと言われてい } \\
\text { る。 }\end{array}$ \\
\hline 保健性 & $\begin{array}{ll}\text { (1) } & \text { 保健衛生施設（病院等) } \\
\text { (2) } & \text { 処理施設 } \\
& \text { (当初は簡単な施設) } \\
\text { ・ 上下水施設 } \\
\text { ・ ごみ処理施設 } \\
\text { ・ し尿施設 }\end{array}$ & 生活環境の確保 & 1900 年〜 & $\begin{array}{l}\text { 公衆衛生の向上 } \\
\left(\begin{array}{l}\text { 健康的な都市生 } \\
\text { 活の確保 }\end{array}\right)\end{array}$ & $\begin{array}{l}\text { •都市の中で廃棄物の投棄による害虫 } \\
\text { (ハエ・コキブリ等) やネズ・・野犬 } \\
\text { 等による細菌性環境污染を防止し, 公 } \\
\text { 衆衛生の向上をはかるため, 公共的に } \\
\text { 廃棄物処理を行う必要があった。 } \\
\text { ・1900年に污物掃除法の公布 } \\
\text { ・1954年に清掃法・都清掃条例の公布 }\end{array}$ \\
\hline \multirow[t]{2}{*}{ 効率性 } & \multirow{2}{*}{$\begin{array}{l}\text { (1) } \\
\text { 教育施設 } \\
\text { 学校・図書館等 } \\
\text { (2) 供給施設 } \\
\text { ・電力・ガス施設 } \\
\text { (3) 交通・流通施設 } \\
\\
\text { 道路・鉄道・港湾・空 } \\
\\
\text { 港施設等 } \\
\text { (4) 情報施設 } \\
\\
\text { 電話・郵便・ラジオ・ } \\
\text { テレビ施設 }\end{array}$} & \multirow[b]{2}{*}{$\begin{array}{l}\text { 利便・生産環境の } \\
\text { 確保 }\end{array}$} & \multirow[b]{2}{*}{1970 年 $\rightarrow$} & $\begin{array}{l}\text { 環境衛生の向上 } \\
\left(\begin{array}{l}\text { 廃棄物処理の量 } \\
\text { 的管理 }\end{array}\right)\end{array}$ & $\begin{array}{l}\text { ・都市の美観の維持もさることながら, } \\
\text { 都市化の進展にともない急増する廃棄 } \\
\text { 物を, 量的に処理しうろ処理施設を整 } \\
\text { 備する必要があった。 } \\
\text { ・1964年に東京オリンピックが開催さ } \\
\text { れた。 }\end{array}$ \\
\hline & & & & $\begin{array}{l}\text { 廃棄物の適正処理 } \\
(\text { 二次公害の防止) } \\
\left(\begin{array}{l}\text { 廃棄物処理の質 } \\
\text { 的管理による都 } \\
\text { 市の環境管理 }\end{array}\right)\end{array}$ & $\begin{array}{l}\text { ・1970年公害防止法令が施行される。 } \\
\text { ・1970年廃棄物処理法が施行される。 } \\
\text { ・廃プラスチックに見るような廃棄物の } \\
\text { 質的多様化に応した適正な処理システ } \\
\text { ムを構築し, 廃棄物処理にともなう化 } \\
\text { 学的㻴境污染の防止対策が必要になっ } \\
\text { た。 } \\
\text { ・こみ焼却施設・廃棄物処分場浸出水処 } \\
\text { 理施設・し尿処理施設の公害防止対策 } \\
\text { の充実 } \\
\text { ・1978年に第二次石油危機が発生 }\end{array}$ \\
\hline $\begin{array}{l}\text { 快適性 } \\
\text { 創造性 }\end{array}$ & $\begin{array}{l}\text { (1) 美術館 } \\
\text { (2) 博物館 } \\
\text { (3) 大劇場 } \\
\text { (4) オペラ座 } \\
\text { (5) スポーツセンター } \\
\text { (6) 都市景観の形成 }\end{array}$ & $\begin{array}{l}\text { アメニティーの確 } \\
\text { 保 }\end{array}$ & 1980 年代 & $\begin{array}{l}\text { 資源循環型の廃棄 } \\
\text { 物処理 } \\
\text { （資源保全管理） }\end{array}$ & $\begin{array}{l}\text { ・高度成長した日本国内では成熟社会に } \\
\text { 到達したか, 地球上のフロンティアー } \\
\text { は無くなり, 限られた資源を有効に利 } \\
\text { 用していかないと, 現在の生活水準を } \\
\text { 維持していけないのではの懸念から, } \\
\text { 極力廃棄物の資源再生をはかる廃棄物 } \\
\text { 処理システムの構築か必要になった。 } \\
\text { ・1995年容器包装リサイクル法の公布 } \\
\text { ・1998年家電リサイクル法令の公布 }\end{array}$ \\
\hline $\begin{array}{l}\text { 持続性 } \\
\text { 共存性 } \\
\text { 自立性 }\end{array}$ & $\begin{array}{l}\text { 1) グローバルな環境・資 } \\
\text { 源の制約を大前提に, 人類 } \\
\text { を含む地球上の生物が永続 } \\
\text { 的に共生できる社会の出現 } \\
\text { が望まれている。 } \\
\text { (2) 特にエコロジー指向型 } \\
\text { (環境負荷が小さい)・資 } \\
\text { 源循環型の都市施設へ転換 } \\
\text { していくことが求められて } \\
\text { いる。 }\end{array}$ & $\begin{array}{l}\text { エコロジーへの配 } \\
\text { 虑(環境倫理) }\end{array}$ & 2000 年〜 & 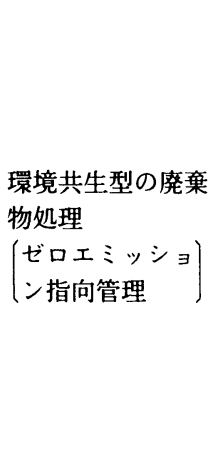 & 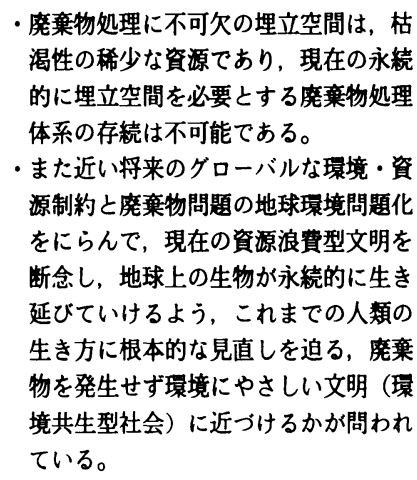 \\
\hline
\end{tabular}


き延びていけるように，個人がこれは不要として廃棄 物にする判断基準の変更を迫られていると考える。こ れまでは保健衛生面・利便性・快適性等の自己満足的 な基準で廃棄物にする判断をしてきた。しかし，今後 は, 子孫達の永続的な生存を保証する持続性・生物の 多椂性を確保する共存性・他者を檥牲にしない自立性
等, 環境共生的な観点に立つ基準も加えて, 廃棄物に するかどうかの判断が求められている。

つまり，人間も生物連鎖の一部でしかなく，絶対的 な地球生態系の制約下で生き延びていく目標の社会像 として,「環境共生型社会の構筑」が不可欠のキー ワードであると考える。

\section{正 誤 表}

Vol. 36 No.11（1999年11月）から Vol. 37 No. 4 （2000年 4 月）までの誤植等の訂正表を以下に掲載しました。 著者からの申し出，読者からの指摘によって年間約 2 回に分けて揭載する予定です。

\begin{tabular}{|c|c|}
\hline 誤 & 正 \\
\hline $\begin{array}{l}\text { Vol. } 36 \text { No. } 11 \\
\text { 英文誌Vol. } 11 \text { (2000年) の予約購読料 p. } 869 \\
\text { ・D M (ドィツマルルク） } \underline{460 て ゙ す 。 ~}\end{array}$ & •씨です。 \\
\hline $\begin{array}{l}\text { Vol. } 37 \text { No. } 3 \\
\text { 埋め草p. } 204 \text { ·奇書 }\end{array}$ & ·宣書 \\
\hline $\begin{array}{l}\text { Vol. } 37 \text { No. } 4 \\
\begin{array}{rlrl}\text { 海外報告 } & \text { p. } 300 & \text { 表 } 1 & \cdot \text { 松本幹三教授 } \\
& & \cdot(\underline{\text { Liming Hu }}) \text { 教授 } \\
& & \cdot \text { 菊島 和宣氏 } \\
& \text { p. } 301 & \text { 表 } 2 & \cdot \text { 蒙古 }\end{array}\end{array}$ & 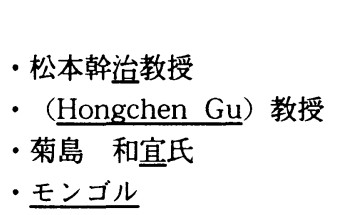 \\
\hline
\end{tabular}

